\title{
ANALISIS KEMAMPUAN PEMECAHAN MASALAH MATEMATIS PADA MATERI ALJABAR SMP BERDASARKAN DISPOSISI MATEMATIS
}

\author{
Neneng Tita Rosita ${ }^{1}$ Lia Yuliawati ${ }^{2}$ \\ ${ }^{1,2}$ STKIP Sebelas April \\ 1titayusepa79@gmail.com, ${ }^{2}$ liajlwt@gmail.com
}

\begin{abstract}
Abstrak
Kemampuan pemecahan masalah matematis merupakan salah satu fokus pembelajaran matematika. Dalam belajar matematika seringkali siswa menemukan soal yang tidak dengan segera dapat dicari solusinya, dan siswa diharapkan dapat memecahkan soal tersebut. Disposisi matematis berkaitan dengan bagaimana siswa memandang dan menyelesaikan masalah; apakah percaya diri, tekun, berminat, dan berpikir terbuka untuk mengeksplorasi berbagai alternatif strategi penyelesaian masalah. Tujuan penelitian menghasilkan penjenjangan disposisi matematis dan mengidentifikasi kemampuan pemecahan masalah siswa SMP pada materi aljabar pada tiap tingkat disposisi. Metode penelitian ini kualitatif. Subyek penelitian sebanyak 21 siswa. Instrumen penelitian adalah soal tes kemampuan pemecahan masalah materi aljabar yang telah dirancang berdasarkan indikator pemecahan masalah dengan langkah Polya. serta wawancara terhadap subyek sebagai triangulasi. Penelitian ini menghasilkan penjenjangan disposisi matematis tinggi, sedang, dan rendah. Hasil tes kemampuan pemecahan masalah materi aljabar bahwa sebagian besar subjek berada pada tingkat disposisi sedang, subjek disposisi rendah dan disposisi sedang mengalami kesulitan dalam membaca dan menafsirkan soal, membuat simbol aljabar dan membuat model matematika sehingga tidak dapat memecahkan masalah yang diberikan. Sedangkan subjek disposisi tinggi mampu memenuhi semua indikator-indikator kemampuan pemecahan masalah meskipun belum sempurna. Subjek disposisi tinggi memiliki kemampuan pemecahan masalah yang lebih tinggi daripada siswa subjek disposisi sedang dan disposisi rendah.
\end{abstract}

Kata kunci: Pemecahan Masalah, Disposisi Matematis, Materi Aljabar SMP.

\section{PENDAHULUAN}

Kemampuan pemecahan masalah matematis penting untuk dikembangkan karena kemampuan pemecahan masalah matematis dapat membantu menyelesaikan permasalahan yang dihadapi, untuk mengantisipasi perkembangan ilmu pengetahuan dan permasalahan kehidupan sehari-hari. Ruseffendi (1991a: 103) mengatakan bahwa kemampuan pemecahan masalah sangat penting dalam matematika, bukan saja bagi mereka yang dikemudian hari akan mendalami atau mempelajari matematika, melainkan juga bagi mereka yang akan menerapkannya dalam bidang studi lain dan dalam kehidupan sehari-hari. Pemecahan masalah harus menjadi tujuan utama pengajaran dan pembelajaran matematika, memberi kesempatan pada setiap peserta didik untuk terlibat dalam kegiatan pemecahan masalah (NCTM, 2000). Lebih lanjut menurut Branca (Sumarmo, 2013: 445) menyatakan bahwa pemecahan masalah matematik merupakan salah satu tujuan penting dalam pembelajaran matematika, bahkan proses pemecahan masalah matematik merupakan jantungnya matematika.

Sumarmo (2013: 128) menjelaskan bahwa pemecahan masalah matematik mempunyai dua makna yaitu: (1) pemecahan masalah sebagai suatu pendekatan pembelajaran, yang digunakan untuk menemukan kembali (reinvention) dan memahami materi, konsep, dan prinsip matematika. Pembelajaran diawali dengan penyajian masalah atau situasi yang kontekstual kemudian melalui induksi siswa menemukan konsep/prinsip matematika; (2) sebagai tujuan atau kemampuan yang harus dicapai, yang dirinci menjadi lima indikator meliputi: 1) mengidentifikasi kecukupan data untuk pemecahan masalah;2) membuat model matematik dari 
suatu situasi atau masalah sehari-hari dan menyelesaikannya; 3) memilih dan menerapkan strategi untuk menyelesaikan masalah matematika dan atau di luar matematika; 4) menjelaskan atau menginterpretasikan hasil sesuai permasalahan asal, serta memeriksa kebenaran hasil atau jawaban; dan 5) menerapkan matematika secara bermakna.

George Polya dalam How to Solve It secara garis besar mengemukakan empat langkah utama dalam pemecahan masalah yaitu: 1) Memahami masalah (Understanding the Problem); 2) Menyusun rencana pemecahan (Devising a Plan); 3) Melaksanakan rencana (Carrying out the Plan); dan 4) Memeriksa kembali (Looking Back). Sehingga Indikator pemecahan masalah matematis dalam penelitian ini adalah: (1) mengidentifikasi kecukupan data untuk pemecahan masalah; (2) membuat model matematik dari suatu situasi atau masalah sehari-hari dan menyelesaikannya; (3) memilih dan menerapkan strategi untuk menyelesaikan masalah matematika dan atau di luar matematika; (4) menjelaskan atau menginterpretasikan hasil sesuai permasalahan asal, serta memeriksa kebenaran hasil atau jawaban

Disposisi matematis merupakan salah satu faktor yang menentukan keberhasilan belajar siswa. Siswa memerlukan disposisi yang akan menjadikan mereka gigih menghadapi masalah yang lebih menantang dan mengembangkan kebiasaan baik pada pembelajaran matematika. Menurut Widjajanti (2011: 3) berpendapat bahwa seorang peserta didik yang mempunyai disposisi produktif yang tinggi cenderung akan mampu mengembangkan kecakapan matematis mereka dalam hal pemahaman konseptual, kelancaran prosedural, kompetensi strategis, dan penalaran adaptif. Kemudian Wardani (2009: 15) mendefinisikan disposisi matematis adalah ketertarikan dan apresiasi terhadap matematika yaitu kecenderungan untuk berpikir dan bertindak dengan positif, termasuk kepercayaan diri, keingitahuan, ketekunan, antusias dalam belajar, gigih menghadapi permasalahan, fleksibel bersedia berbagi dengan orang lain, reflektif dalam kegiatan matematis.

Menurut NCTM (2000: 233) beberapa aspek disposisi matematis, yaitu: (1) kepercayaan diri dalam menyelesaian masalah matematika, mengkomunikasikan ide-ide, dan memberi alasan; (2) fleksibilitas dalam mengeksplorasi ide-ide matematis dan mencoba berbagai metode alternatif untuk memecahkan masalah; (3) bertekad kuat untuk menyelesaikan tugas-tugas matematika; (4) ketertarikan, keingintahuan, dan kemampuan untuk menemukan dalam mengerjakan matematika; (5) kecenderungan untuk memonitor dan merefleksi proses berpikir dan kinerja diri sendiri; (6) menilai aplikasi matematika dalam bidang lain dan dalam kehidupan sehari-hari; dan (7) mengapresiasi peran matematika dalam budaya dan nilainya, baik matematika sebagai alat, maupun matematika sebagai bahasa. Berdasarkan uraian tersebut aspek-aspek disposisi matematis dalam penelitian ini antara lain: (1) percaya diri dalam pembelajaran matematika dan menyelesaikan berbagai masalah; (2) fleksibel dalam mengeksplorasi ide-ide matematika dan mencoba berbagai alternatif metode dalam menyelesaikan berbagai masalah; (3) kegigihan dalam menyelesaikan permasalahan matematika; (4) memiliki rasa keingintahuan dan bersungguh-sungguh dalam pembelajaran matematika; (5) memonitor dan merefleksi hasil kerja dan pemikirannya sendiri; (6) memaknai aplikasi-aplikasi matematika pada situasi-situasi yang muncul pada bidang-bidang lain dan kehidupan sehari-hari; dan (7) mengapresiasi peran matematika dalam budaya dan nilainya.

Aljabar adalah bahasa untuk menyelidiki dan mengkomunikasikan sebagian besar Matematika. Aljabar merupakan salah satu materi yang dipelajari oleh siswa kelas VII SMP. Pada tingkat ini siswa mulai mengalami perubahan yang signifikan dalam proses berpikir yaitu dari berpikir aritmatik menjadi berpikir aljabar (abstrak). Aljabar merupakan suatu cara 
berpikir, suatu kumpulan konsep, dan keterampilan yang memungkinkan siswa melakukan generalisasi, memodelkan, dan menganalisis situasi matematika (NCTM, 2000). Lebih lanjut dalam Prinsip dan Standar Matematika Sekolah (NCTM, 2000), terdapat empat tujuan yang tercantum terkait dengan aljabar: 1. Pahami pola, hubungan, dan fungsi; 2. Merepresentasi dan menganalisis situasi dan struktur matematika dalam menggunakan simbol aljabar; 3 . Menggunakan model matematis untuk mewakili dan memahami hubungan kuantitatif; dan 4. Menganalisis perubahan dalam berbagai konteks. Lebih lanjut Watson (2007: 3) mengemukakan aljabar adalah cara kita menyatakan generalisasi tentang bilangan, kuantitas, relasi dan fungsi. Menurut Kieran (1996), aktivitas generasi aljabar melibatkan pembentukan ungkapan dan persamaan yang merupakan khas objek aljabar yang meliputi: 1. persamaan yang mengandung unsur tidak diketahui yang mewakili situasi masalah 2. ungkapan umum yang timbul dari pola geometris atau urutan numerik dan 3. ungkapan dari aturan yang mengatur hubungan numerik.

Hasil yang sangat memprihatinkan dari laporan terbaru PISA tahun 2010, Indonsia hanya mampu nenempati peringkat ke-3 dari yang terendah (Zulkardi, 2010). Sedangkan hasil dari TIMSS (Third International Mathematics and Science Study) menunjukan Indonesia pada mata pelajaran Matematika berada di peringkat 34 dari 38 negara. Soal-soal yang disajikan dalam kompetisi PISA dan TIMSSS merupakan soal-soal non rutin. Selain itu, mengingat bahwa peserta yang mewakili Indonesia dalam kegiatan PISA adalah anak usia SMP (OECD, 2010) buruknya peringkat Indonesia di PISA menunjukan bahwa mayoritas siswa SMP di Indonesia masih lemah dalam menghadapi masalah matematika terutama soal-soal non rutin. Ini berarti masih banyak kemampuan-kemampuan serta sikap-sikap yang belum dimiliki oleh siswa yang diperlukan untuk menghadapi masalah dalam soal matematika nonrutin. Kemudian berdasarkan informasi dari guru mata pelajaran matematika SMP sebagian besar soal-soal UN tahun ajaran 2015-2016 adalah soal pemecahan masalah pada materi aljabar dan hasilnya sangat rendah. Kemudian Hasil penelitian Dwi, A., Marsetyorini, dan Ch. Enny (2012) menemukan kesulitan belajar siswa kelas VIII SMPN 2 Jetis Bantul dalam materi operasi pada pecahan bentuk aljabar terletak pada kesalahan dalam memahami materi pecahan dalam bentuk aljabar, kurangnya penguasaan materi prasyarat seperti materi faktorisasai aljabar, operasi hitung bentuk aljabar, dan operasi hitung bilangan bulat. Hal ini membuat kesulitan yang dialami pada setiap orang berbeda. Sehingga dari uraian tersebut perlu dilakukan suatu analisis untuk mengetahui kemampuan pemecahan masalah pada materi aljabar SMP ditinjau dari disposisi matematis siswa.

\section{METODE PENELITIAN}

Metode yang digunakan dalam penelitian ini menggunakan metode kualitatif. Subjek sebanyak 21 siswa kelas VII SMP Negeri Sumedang. Instrumen penelitian soal tes uraian kemampuan pemecahan masalah materi aljabar, angket skala disposisi matematis, serta wawancara terhadap subjek sebagai triangulasi. Soal yang telah dirancang berdasarkan indikator pemecahan masalah dengan langkah Polya. Fokus penelitian ini adalah menganalisis kemampuan pemecahan masalah matematis pada materi aljabar berdasarkan disposisi matematis siswa. 


\section{HASIL DAN PEMBAHASAN}

Tahap analisis hasil penilaian soal tes, dilihat kredibilitas dari soal yang telah dibuat. Terdapat dua dari tiga ahli menyatakan credible (dapat dipercaya) maka disimpulkan soal tes kemampuan pemecahan masalah dapat digunakan dalam penelitian. Analisis data hasil penggunaan instrumen soal tes berorientasi kepada masalah dan tujuan penelitian yaitu mendeskripsikan atau menghasilkan penjenjangan disposisi matematis pada materi aljabar, kemudian mengidentifikasi kemampuan pemecahan masalah siswa SMP kelas VII pada materi aljabar pada tiap tingkat disposisi.

Dari hasil tes soal kemampuan pemecahan masalah dengan terlebih dahulu memberikan angket skala disposisi matematis untuk mengelompolan siswa pada tiap tingkat disposisi. Dari hasil angket skala disposisi matematis diperoleh terdapat tiga penjenjangan disposisi yaitu tinggi, sedang, dan rendah dengan subjek disposisi tinggi sebanyak 4 siswa(19\%), subjek disposisi sedang 12 siswa (57,15\%), dan subjek disposisi rendah sebanyak 5 siswa $(23,81 \%)$. Dari hasil analisis tes kemampuan pemecahan masalah pada materi aljabar dengan langkah Polya dan hasil wawancara terlihat bahwa keduanya konsisten.

Kemudian mengambil subjek yaitu dengan mengambil tiga siswa dari tiap tingkat disposisi untuk mengidentifikasi lebih mendalam kemampuan pemecahan masalah pada materi aljabar pada tiap tingkat disposisi matematis. Hasil analisis digambarkan dalam Tabel berikut secara keseluruhan hasil kemampuan pemecahan masalah pada materi aljabar ditinjau dari disposisi matematis sebagai berikut

Tabel 1

\section{Hasil Analisis Data Kemampuan Pemecahan Masalah pada Materi Aljabar ditinjau dari Disposisi Matematis}

\begin{tabular}{|c|c|c|c|}
\hline Indikator & $\begin{array}{l}\text { Disposisi } \\
\text { tinggi }\end{array}$ & $\begin{array}{l}\text { Disposisi } \\
\text { sedang }\end{array}$ & $\begin{array}{l}\text { Disposisi } \\
\text { rendah }\end{array}$ \\
\hline Mengidentifikasi kecukupan data & $\sqrt{ }$ & $\sqrt{ }$ & $\sqrt{ }$ \\
\hline Membuat model matematika & $\sqrt{ }$ & $\sqrt{ }$ & - \\
\hline $\begin{array}{l}\text { Menerapkan strategi untuk } \\
\text { menyelesaikan masalah }\end{array}$ & $\sqrt{ }$ & $\sqrt{ }$ & - \\
\hline $\begin{array}{l}\text { Menginterpretasikan/memeriksa } \\
\text { kebenaran }\end{array}$ & $\sqrt{ }$ & - & - \\
\hline
\end{tabular}

Berdasarkan Tabel $1 \mathrm{di}$ atas hasil temuan menujukkan bahwa mayoritas sebanyak 19 subjek Pada subjek disposisi rendah dan sedang, subjek pada tingkat ini mengalami kesulitan dalam hal membaca dan menafsirkan soal cerita yang diberikan, kesulitan dalam membuat simbol aljabar sehingga tidak dapat menuliskan variabel-variabel yang diketahui, kesulitan dalam membuat simbol aljabar juga mengakibatkan subjek tidak dapat menyelesaikan tahapan berikutnya yakni membuat model matematika, dan tentunya tidak dapat menyelesaikan masalah. Hal ini diakibatkan subjek tidak memahami dari unsur aljabarnya sendiri seperti variabel, koefisien, dan konstanta kemudian masih keliru dalam mengoperasikan bilangan dalam bentuk aljabar, mereka gagal dalam menghubungkan pola linear yang diberikan dalam pertanyaan karena kurangnya konsep aljabar terutama tentang apa yang diketahui (variabel) dan persamaan linear. 
Sebagian subjek disposisi sedang memiliki kemampuan pemecahan masalah pada materi aljabar: membaca dan menafsirkan soal cerita, menggunakan simbol aljabar, mengeneralisasi hubungan linear dari pola secara simbolis dari simbol aljabar kemudian membuat model matematika berdasarkan semua informasi yang diberikan, menjalankan strategi untuk menyelesaikan masalah yang diberikan. Walaupun masih ada subjek ini yang mengalami kesulitan dalam membuat model matematika. Studi ini sesuai dengan temuan penelitian Yusepa (2016) bahwa hanya $13,8 \%$ siswa yang dapat membuat model matematis yang tepat. Subjek ini juga mengalami kesulitan dalam menjelaskan atau menginterpretasikan hasil sesuai permasalahan asal, serta memeriksa kebenaran hasil atau jawaban.

Subjek disposisi tinggi hampir memenuhi semua indikator-indikator kemampuan pemecahan masalah walaupun masih ada yang keliru dalam menginterpretasikan hasil yang sesuai dengan permasalahan asal.

Penelitian tentang aljabar ini sesuai dengan hasil penelitian yang menunjukkan adanya beberapa perspektif guru tentang apa yang penting dalam pengajaran aljabar sekolah (Bednarz, Kieran \& Lee, 1996; Usiskin, 1988). Para guru juga menganggap aljabar lebih banyak tentang penggunaan dan manipulasi simbol daripada tentang penerapan, komunikasi atau penalaran tentang gagasan aljabar.

\section{KESIMPULAN}

Dari hasil dan pembahasan di atas diperoleh kesimpulan sebagai berikut: 1. Sebagian besar subjek berada pada tingkat disposisi sedang; 2. pada subjek disposisi rendah dan sedang subjek mengalami kesulitan dalam membaca dan menafsirkan soal cerita sehingga tidak dapat menyelesaikan langkah berikutnya 3. Subjek disposisi tinggi memenuhi hampir semua indikator kemampuan pemecahan masalah dicapai walaupun belum sempurna dalam menadinterpretasikannya.

Saran atau rekomendasi kepada pendidik dan peneliti dari hasil penelitian ini agar memperhatikan hal-hal berikut dalam pengajaran, yaitu: 1) penggunaan model atau pendekatan pembelajaran harus tepat sesuai dengan karakteristik materi dan juga karakteristik siswa; 2) penggunaan model pembelajaran harus bervariasi; 3) penggunaan bahan ajar untuk membantu siswa memahami materi aljabar dan lebih aktif saat kegiatan pembelajaran berlangsung.

\section{REFERENSI}

Bednarz, N., Kieran, C., \& Lee, L. (1996). Approaches to Algebra: Perspective for Research and Teaching. Dordrecht: Kluwer.

Dwi, A., Marsetyorini, dan Ch. Enny (2012). Diagnosis Kesulitan Belajar Siswa Dan Pembelajaran Remedial Dalam Materi Operasi Pada Pecahan Bentuk Aljabar Kelas VIII SMP N 2 Jetis Bantul.

Kieran, C. (1992). The learning and teaching of school algebra. In D. A. Grouws (Ed.), Handbook of research on mathematics teaching and learning (pp. 390-419). New York, NY: Macmillan.

NCTM. (2000). Defining Problem Solving. [Online]. Tersedia: http://www.learner.org/channel/courses/teachingmath/gradesk 2/session 03/sectio 03 a.html. [25 Mei 2016].

OECD. (2010).PISA 2009 Results: What Students Know and Can Do - Student Performance in Reading, Mathematics and Science(Volume I) http://dx.doi.org/10.1787/9789264091450enISBN 978-92-64-09144-3 (print)ISBN 978-92-64-09145-0 (PDF) 
Polya, G. (1985). How to solve it: A new aspect of mathematics method ( $2^{\text {nd }}$ ed). Princeton, New Jersey: Princeton University Press.

Ruseffendi, E.T. (2006). Pengantar kepada Membantu Guru Mengembangkan Kompetensinya dalam Pengajaran Matematika Untuk Meningkatkan CBSA. Bandung: Tarsito.

Sumarmo, U. (2013). Kumpulan Makalah: berpikir dan disposisi matematik serta pembelajarannya. Bandung: Universitas Pendidikan Indonesia.

Usiskin, Z. (1988). Conceptions of school algebra and uses of variables. In A. F. Coxford (Ed.), The Ideas of Algebra, K-12. 1988 Yearbook (pp. 8-19). Reston, Virginia: NCTM.

Yusepa, B. G.P. (2016). Analisis Kesuliatn Siswa Dalam

Watson, A. Key Understanding of Mathematics Learning. Paper 6: Algebraic Reasoning. Nuffield Foundation. University of Oxford. (2007) diakses http://www.nuffieldfoundation.org/sites/default/files/P6.pdf 20 Nopember 2016

Wardani, S. 2009. Meningkatkan kemampuan berfikir kreatif dan disposisi matematik siswa SMA melalui pembelajaran dengan pendekatan model Sylver. Disertasi: Bandung. Program Pascasarjana Universitas Pendidikan Indonesia.

Zulkardi. (2010). "PMRI (Pendidikan Matematika Realistik Indonesia): dulu, kini dan nanti”.Makalah pada Kuliah Umum Pendidikan Matematika UPI, Bandung. 